\title{
SIR HARRY PLATT
}

\section{An Appreciation by H. Osmond-Clarke}

That Harry Platt has lived for eighty years is no surprise to those of us who remember his doughty parents, both of whom reached the age of ninety, and the remarkable athletic powers of his brothers, especially in the world of hockey. H. P. himself was deprived of participation in sport by a knee infection which invalided him for years and was responsible for his contact early in life with Sir Robert Jones who treated him. No doubt this contact influenced him towards a career in medicine, and especially in orthopaedics, and surely the physical set-back must have bred in him the remarkable tenacity of purpose which has always been such a notable feature of his character, and of his approach to life's problems. It may well be, too, that inability to play games allowed him to concentrate on intellectual activitiesliterature, history, especially American history, and music. In the twenties and thirties in Manchester he was an ardent and faithful attender at Hallé concerts and was himself a pianist of high amateur competence; it was always a great pleasure to listen to him, and why he gradually gave it up only he himself knows.

Since his training in Boston before the first world war he has been a keen supporter of Anglo-American relations and prominent in the affairs of the English-speaking Union. To us youngsters working with him it was always a pleasure to observe the warmth with which he received foreign visitors of all ages, and especially Americans and Europeans, an attitude in striking contrast to that of most of his London contemporaries. He himself was, and is, an ardent traveller, and in this way and by his writings has close personal contacts in orthopaedics all over the world. It is fitting that in his eightieth year he should still be President of the International Federation of Surgical Colleges. No one in orthopaedics-not even Robert Jones himself-has held so many presidencies. A presidency appeals to his somewhat egotistical outlook; he usually regards himself as more enlightened than the average medical man on matters of medical education at all levels, on political philosophy and indeed, on a host of other subjects-and with good reason. On how to run things and get things done he is a self-confessed supporter of the belief that the best committee is a committee of one.

Training under him in Manchester in the twenties and thirties was a hard-working, tough but exciting and stimulating experience, first at Ancoats Hospital where he organised the first segregated fracture department certainly in Great Britain, and probably in the world, just after the first world war; and from 1932 onwards at the Manchester Royal Infirmary where he organised and directed the first orthopaedic and fracture department of that hospital. Training for his pupils was mostly by apprenticeship, in out-patients, in the wards and in the operating theatres. We also had bi-monthly evening meetings in his lovely home in Victoria Park where the orthopaedic literature of the day from all countries was discussed. He always received the major journals of Europe and America, tore out the important articles and handed them to his team for abstraction and discussion at these evening meetings. This often meant for his pupils work far into the night on an article in a completely unknown language with only the help of a dictionary. These sessions were always " mixed," for H. P. was one of the first to attract women house-officers and to appreciate how valuable they were 
in orthopaedics, and particularly in the management of children. These evenings inevitably ended in refreshments, with H. P. at the piano; they remain fresh in the mind of at least one of his pupils as among the most stimulating and rewarding parts of his training. They whetted the appetite for travel; H. P. insisted almost dictatorially that a youngster should spend his annual leave on a "busman's holiday." But that was in the days when housemen and registrars remained single until fully trained and established in consultant posts. To make firm contacts while training with one's opposite numbers in other clinics at home and abroad makes for happy and rewarding friendships for life; it is a sound global policy and H. P. was certainly a great promoter of it.

Sessions in the operating theatres were an education in organisation, in aseptic ritual with firm insistence on no-touch technique, and in demonstrations of superb anatomical approaches. A fine anatomist himself, H. P. taught us that an adequate exposure was an absolute prerequisite for competent and safe surgery. In retrospect this was valuable indoctrination; the disasters of inadequate exposures are still too frequently seen.

At all operating sessions there was usually a display of irascibility, for he found delays on the part of anaesthetists, sisters and assistants intolerable. A favourite trick was kicking at the nearest bucket, a habit interrupted by an infuriated sister who filled the bucket with plaster of Paris: a severely stubbed toe had a dampening effect for some time.

But life in training was not all work. He took a keen interest in the life of the residents' mess, particularly at a time when the mess at Ancoats Hospital was dominated by some of the brighter graduates of Trinity College, Dublin. For a time he was inspired to take up ballroom dancing and it is still widely believed that he chose one house surgeon mainly because of his ability to do the Charleston. As the result of his life-long friendship with the late Rowley Bristow of London-the great bon viveur of orthopaedics-H. P. had a liking for, and knowledge of, good food and wines. Frequently he gave dinner parties for his own and other residents in the French restaurant of the Midland Hotel in Manchester-a luxury restaurant in those days. These dinners were always greatly enjoyed, though we used to hope they would not occur on an evening before an operating session; the repast seemed to aggravate his long-standing duodenitis and make for more than usual turbulence in the operating theatres. But at an early and formative stage we were introduced to the pleasures of good food and delectable wine, a great education which stood us in good if expensive stead in future years.

What of the man himself? A reserved nature, married to a certain amount of intellectual arrogance-perhaps intolerance is a better word-has made it difficult for many to get to know him. Some of us have, however, and we are amused and sometimes enlightened by the astringent-often acidulated-comment on colleagues and affairs in general. We respect profoundly his many great qualities of mind and heart, his organisational capacity, his far-seeing philosophical outlook. We are all grateful for his teaching and training. He is, we hope, proud of his orthopaedic stable which has bred two presidents of the British Orthopaedic Association in his lifetime, one professor of orthopaedic surgery, one councillor of the Royal College of Surgeons of England, and several others holding senior orthopaedic positions in war and in peace, both in this country and abroad.

We salute our chief, a benevolent despot, and wish him well as he leaves his eightieth year. We hope that he will long be with us if only to remind us that what we, his pupils, acquired from him has been lasting and beneficial in our contributions to orthopaedics at home and overseas.

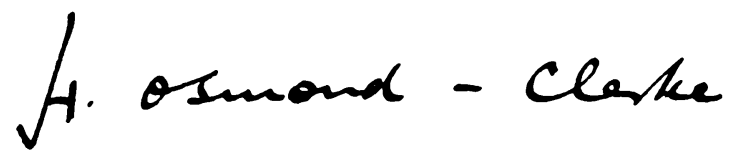

VOL. $48 \mathrm{~B}$, NO. 4, NOVEMBER 1966 